\title{
FINNISH MISSION HISTORY: A STUDY ON SOCIO-CULTURAL IMPACTS MADE BY FINNISH MISSIONARIES IN THE NORTH-EASTERN HIMALAYAS, INDIA
}

\author{
Noel Giri \\ Research Scholar, Centre for Rural Development, Annamalai University, Tamil Nadu-608002
}

Article DOI: https://doi.org/10.36713/epra8726

DOI No: 10.36713/epra8726

\begin{abstract}
Once Winston Churchill rightly said and I quote: "Those that fail to learn from history are doomed to repeat it." History is not just a past to remember but history is an opportunity to explore new things and learn from it. With a great vision and mission-heart, Finnish missionaries came in the Himalayan belt in the early nineteenth century. They had a vision of entering Tibet as soon as they set foot on Indian territory. They stayed and lived difficult lives since India is riven by caste, creed, and regional backwardness, which a few of them (missionaries) correctly termed as "darkness."

The Himalayan people are living considerably more comfortable lives after several decades, yet the efforts and services of Finnish missionaries are still mostly unknown among Himalayan natives. Few of numbers of published articles and books are here to describe their major contributions and chronological evidences of Finnish missionaries' arrival to India.

In this article, a thorough analysis of the socio-economic repercussions of Finnish missionaries in the Himalayan belts and Buxaduars regions of Indian states West Bengal and Sikkim was conducted using collected primary and secondary data.

Therefore, this article carry out this study by collecting data (qualitative and quantitative) and information from various sources viz. Published and unpublished articles and notes, collection of primary data/information from various sources remained in India and Finland and through analysis of historical documents of Finnish Mission History.

KEYWORDS:Finnish missionaries, Himalayas, Socio-economic, mission history, education, community, Scandinavian Alliance Mission, Education, Livelihood, Darjeeling, Sikkim, Buxaduars.
\end{abstract}

\section{A. INTRODUCTION \& BACKGROUND}

Socioeconomic status has been operationalized in various ways, the most common of which are education, class, and income. A continuous refinement of current behavioural patterns, feelings, attitude toward others, and comprehension of others is known as social growth. Community economic development is also a branch of local economic development. Two fundamental concepts underpin community economic development. First, the community or neighbourhood should be the foremost target for developing human, social, and physical resources. Second, for any development effort, indigenous resources, particularly human and organisational resources, must be very cheap. Within the community, economic growth is based on the idea of creating new wealth by repositioning vital local resources as capital attractors. This could be accomplished by re-using local building to incubate local artists and entrepreneurs and other related strategies that restore pride and provides local people more economic power to manage their own economic destiny.

Frederick Franson, an American-Swedish preacher, came in Helsinki, Finland's capital, in October 1888. He led a three-week Bible study programme in Helsinki during his trip. During the session, Reverend Frederick and his colleagues prayed that 


\section{EPRA International Journal of Research and Development (IJRD)}

the Lord would bring them to Tibet in a vision. They established SAM (Scandinavian Alliance Mission) as an organization. The Himalayan Mission was founded in 1892 by the Scandinavian Alliance Mission (SAM). Scandinavians based in North America initiated the Scandinavian Alliance Mission's involvement in the Himalayas. In 1892, J.F. Frederickson, his sister Anna, and ten Canadian missionaries travelled from Vancouver to Kolkata and Darjeeling, only to discover that they were unable to enter Tibet as planned. Instead, they requested for authority to start the mission in India, and they bought the first mission residence in the Ghoom bazar to serve as the main mission station. The nearest stations to Tibet were established near Tibet's southern border in the Sikkimese villages of Lachen and Lachung, and there were expectations that the operations may soon be extended to Tibet as well. The SAM, like all alternative missions around the world, operated under British administration in colonial era. There were also expectations that the Mission may be able to reach Tibet through Bhutan; and a new station has been established near the Bhutan border in Baxaduar for this purpose. Unfortunately, the closing of Tibet was a result of the complicated political situation in Central Asia. Earlier till 17th century, many missionaries had been travelling and staying in Tibet. However, by the 19th century the borders were closed and punctiliously guarded by the Tibetan and Chinese authorities. Even the Tibetans living within the Lachen Valley weren't allowed to enter further to Tibet. Then in India, contacts between the SAM workers and thus nation officials were more or less regular. All permits for purchasing land, establishing new stations, or operating schools had to be obtained from the local or colonial - authority. For missionaries to enter Sikkim, they needed a visa that included a commitment not to enter Tibet. Ms. Sigrid Gahmberg, the first Finnish missionary, arrived in India in 1895 and went to Chunabhatti for mission work. Ms. Klara Hertz, a Finnish missionary, arrived in Ghoom, Darjeeling in August 1896. A school had been operational since 1897, with the goal of educating the locals (particularly children). Four new missionaries (Mr. Carlo Waismaa and his wife Hanna Waismaa, Ms. Massinen, and Hilja Heiskanen) arrived in India in December 1898. Sigrid contracted malaria while on a mission trip in Ghoom and died in 1900. She was laid to rest near the Ghoom mission headquarters. Ms. Klaara Hertz arrived in Lachen (Sikkim) from Finland in 1906 and began working as a missionary. Meanwhile, Massinen grew ill and died in 1908 while on her way back to Finland. Klaara and Elin Kronqvist returned from Ghoom to Lachen in 1909. As a result, the constant presence of Finnish missionaries at regular intervals had a major impact on the Himalayan people in the areas of education, society, culture, religion, and livelihood. After having a tremendous impact on the Himalayan people, nine Finnish missionaries died in Indian soil (Himalayas). Himalayan people have benefited from quality education, improved livelihoods, and societal improvement as time has passed.

\section{B. AIM(S) AND OBJECTIVES}

The major aim is to carry out the proposed research work is as follows -

- To study Finnish missionaries' works and contributions towards the Himalayan people.

- To study social-cultural impacts made by Finnish missionaries towards the Himalayan livelihood.

- To carry out extensive collection of data and information about Finnish mission history from the both sources (India as working field and Finland as their native land).

- To contribute (compile) and secure Finnish missionaries contributions in documented form for future reference.

\section{PROFILE OF THE STUDY AREA}

i. Darjeeling \& Kalimpong Districts:

Darjeeling district is in the state of West Bengal in North-East India, and is situated in the undulating landscape of the eastern Himalayas. It spans the latitudes of $26^{\circ} 27^{\prime} \mathrm{N}$ and $27^{\circ} 13^{\prime} \mathrm{N}$, as well as the longitudes of $87^{\circ} 59^{\prime} \mathrm{E}$ and $88^{\circ} 53^{\prime} \mathrm{E}$. Darjeeling district is bordered on the west by Nepal, on the north by the Indian state of Sikkim, on the east by Bhutan, and on the south by Bangladesh. Darjeeling district comprises the lower Himalaya, as well as Terai (which means "foothill" in Sanskrit and "lands lying at the foot of a watershed" in Urdu) and, to a lesser extent, 'dooars' (which means "gateway/door to Bhutan and North-East India) regions.

The town's name symbolises a place that is synonymous with good times and laughter, leisure and tranquilly, joy and harmony. The phrase Kalimpong loosely translates to "Ridges where we place" in the Lepcha language (Lepchas are the region's indigenous population). Hill tribesmen are said to have congregated in the beauty-decked town in the early phases of its development for leisure purposes.

Kalimpong is surely a spot where tourists can experience an once-in-a-lifetime vacation, with lush green valleys, a panoramic view of the Eastern Himalayan ranges, the snow-capped Kanchenjunga kissing the blue sky, warm weather, and a relaxed attitude. Kalimpong gives its visitors a vacation unlike any other, away from the maddening throng and the hustle and bustle of city life. 


\section{EPRA International Journal of Research and Development (IJRD)}

After centuries of development and refining of its infrastructure, the town is without a doubt one of North East India's most prominent and appealing tourist sites. With the spectacular Kanchenjunga rising in the distance and other prominent Himalayan peaks providing an almost surreal backdrop, this is a picture postcard setting. On a clear day, almost every portion of town offers a nearly 360-degree panoramic view of the snow-capped towering mountains and the pine-draped nearby hills. Kalimpong is not one of those traditional tourist locations where visitors are expected to follow the same schedule as everyone else.

\section{i. Sikkim}

Sikkim was an autonomous political entity for a long time until becoming an Indian protectorate in 1950 and a state in 1975. Despite its tiny size, Sikkim holds significant political and strategic significance for India due to its location along multiple international borders. Sikkim is a state in India's northeast. It is one of India's most populous, multiethnic, and multilingual states. It is bordered on the north and northeast by Tibet, on the east by Bhutan, on the west by Nepal, and on the south by West Bengal. Sikkim is also close to India's Siliguri corridor, which runs across Bangladesh. Sikkim is the smallest and least populous of the Indian states. Sikkim is notable for its biodiversity, including alpine and subtropical climates, as well as being a host to Kanchenjunga, the highest peak in India and third highest on Earth. Sikkim's capital and largest city is Gangtok. Having an area of 7069 sq.kms. the state comprises four (4) districts and sixteen (16) subdivisions.

\section{ii. Jalpaiguri}

The name Jalpaiguri comes from the word "Jalpai," which means "olive," and which grew in the town and surrounding areas as early as 1900. The suffix "guri" denotes a location. The district is situated between $26^{\circ} 16^{\prime}$ and $27^{\circ} 0^{\prime}$ North latitude, and between $88^{\circ} 4^{\prime}$ and $89^{\circ} 53^{\prime}$ East longitude. It is located in the northern section of West Bengal and shares international boundaries with Bhutan to the northeast and Bangladesh to the south. Darjeeling district in the west and northwest, Kalimpong district in the north, Coochbehar district in the southeast, and Alipurduar district in the west share the remaining borders.

The district is mostly made up of rural residents, with a large proportion of SCs/STs (Schedule Castes/Schedule Tribes). The tea gardens, which are found across the district, also house a sizable population. The backbone of the trade industry in this district is 'Tea,' 'Timber,' and 'Tourism.' Agriculture and livestock husbandry are also widely practised in the district.

\section{IMPLICATIONS OF THE STUDY}

The study's major goal is to look into Finnish missionaries' work and contributions to the Himalayan people, as well as their social and cultural impacts on Himalayan livelihood. The findings of the proposed study will aid others in learning more about Himalayan Mission history, as well as its elements and repercussions on local Himalayan livelihood.

\section{E. SOURCES OF DATA}

The required data was collected from different respondents with the help of pre-tested interview and focused group interviews schedules as primary data. The information about the history and works of Finnish missionaries is collected from various published and un-published secondary data sources.

\section{F. ASPECTS OF SOCIO-ECONOMIC IMPACTS MADE BY FINNISH MISSIONARIES IN THE NORTH- EASTERN HIMALAYA}

The principal mission stations during the SAM (Scandinavian Alliance Mission) were Ghoom in Darjeeling, Buxaduars in the Dooars (Jalpaiguri district), and Lachung, Mangan, and Lachen in North Sikkim. Later, new workstations sprang up around each station, such Alubaari in Ghoom, Bob and Soong in Sikkim, and Adama in the Buxaduars.

In the fields of education, society, culture, religion, and livelihood, the frequent presence of Finnish missionaries at regular intervals had a major impact on the Himalayan people. After having a tremendous impact on the Himalayan people, nine Finnish missionaries perished in Indian soil (Himalayas). The Finnish missionaries provided superior education, improved livelihoods, and societal upliftment to Himalayas over time.

1. Children's Home named "Sparrow's Nest" In 1909, the Finnish Missionaries Hilja Heiskanen founded "Sparrow's Nest," a children's home where children were brought from Ahmedabad (Gujarat) during the late nineteenth century (1899-1901). Ghoom and the surrounding area were once part of Sikkim, but the borders moved over time, and each conqueror left their mark. The Darjeeling Himalayan Railway (DHR) and Darjeeling Tea Gardens boosted the residents' options to make money in the 19th century, resulting in a continual flow of immigrants, mainly from Nepal. The people, particularly the Lepchas, quickly mastered Nepali, and the Tibetan and 
Lepcha place names are now merely relics of the past.

Sparrow's Nest's main goal was to offer housing for the homeless and impoverished, as well as to provide quality education as possible. Here's an example of a Brahmin (Bahun) family race from Nepal called Sharma - From Nepal, seven members of a Brahmin family arrived. Sadly, spouse died at a young age after arriving at Ghoom. His wife and five children fled to a different location without a backbone. The widow mother was later forced to sell her children into slavery (Child labour) after becoming unwell. The eldest son was able to sustain himself in some way. When Finnish missionaries learned of the widow family's story, they took their children to the Sparrow's nest and began caring for the entire family.

Three of them (James Sharma, David Sharma, and Ruth Sharma) went on to become theologians, teachers, and doctors, respectively. Sparrow's nest children's home was afterwards moved to Buxaduars by Edla Traskback and Hanna Juureva in the year 1930. In 1956, a tiny boarding hostel in Ghoom was established with a few school-aged youngsters from Sikkim and the Buxaduars.

\section{Educational Institutions and Women}

Empowerment through Education

Christian missions pioneered Western education in the Darjeeling district. The Church of Scotland was instrumental in the establishment of several schools in Darjeeling and Kalimpong. Finnish missionaries established a tiny elementary school in Ghoom, Darjeeling. In 1904, there were a total of 42 (forty-two) pupils registered for school, representing many countries and beliefs. Separate classes for boys and girls had previously been held. Every Saturday, villagers' children receive a special lesson because they are unable to attend school throughout the week.

Hilja Heiskanen, a missionary, was passionate about girls' education and women's empowerment through effective and highquality education for girls. Separate classes for girls had been established for this reason alone. In 1907, the school was upgraded and designated as an English Secondary School. The school had 102 students and six teachers in 1924. After an earthquake in 1934 (Nepal-India Earthquake popularly known as Bihar-Nepal earthquake, 1934), the school had to close. Mariam-mati Rai, who grew up at the Children's Home called Sparrow's Nest, was the teacher when the school reopened in the following years. Later, in 1958, the school became a secondary school, with Late David Mangratee as principal, who was also the pastor of Ghoom Church at the time. At the time, the school had about 200 students and six teachers. When the missionaries left the Ghoom, the state government took over the institution.

\section{Weaving Industry}

J. Claude developed a cottage industry by founding a weaving school in Lachen and Lachung, North Sikkim, as part of economic and livelihood reforms in rural Sikkim. The Swedes Mathilda Johansson and Signe Fredreicksson ran a weaving school in Lachung until Finnish missionary Anna Massinen and then Edla Traskback arrived. In the year 1921, Edla Traskback established a comparable weaving factory in Ghoom. Hanna Juureva (Edla's coworker) opted to using cotton yard in Ghoom and trained the weavers how to manufacture items for western clients. Tablecloths, pillow covers, handkerchiefs, coffee pot covers, and various curtains were among the most popular weaving products. Similar cottage weaving industries existed in Sikkim, where cotton textile was produced on narrow looms for the households' own use and using yarn primarily imported. Vegetable materials discovered in the forests had been widely used for dying purposes. Later, industrial (artificial) aniline colours were used to replace dying colours of vegetables.

The weaving business, which was led by Finnish missionaries, was dominated by local girls and women. The main woven goods of Sikkim's cottage industry were carpets and woollen blankets. Locals (adult men and women), children, and women learning the knitting used to meet at Mission House every morning and evening. Hanna and Edla used to transport woven handicrafts to Calcutta for sale every year, and the profits were used to pay the workers' wages and fund for numerous community activities.

Edla Traskback and Hanna Juureva later moved the weaving industry cum shop to Buxaduars in 1930. The weaving shop provided Himalayan women with an excellent opportunity to develop self-employment and self-sustainability in terms of their livelihood. The Himalayan society's socioeconomic sustainability had been brought about by the weaving cottage industry. 


\section{EPRA International Journal of Research and Development (IJRD)}

4. Health Care and Hospital and awareness on various superstitious beliefs

Missionary Edla Traskback's favourite work, aside from weaving, was nursing, as she had studied childbirth care, natural healing, and home nursing in her youth. Ruth Longman Sharma, once a Sparrow' Nest child, went on to become an ophthalmologist and open a small hospital in Ghoom. Ruth's brother James's wife was a professional nurse who assisted with nursing duties at the hospital, and Edla Traskback was a patron of the institution. They used to take patients from all across Darjeeling, including Ghoom.

Anna Massinen, who got dried blueberries from Finland, applied cold wrappings and blueberry beverages for natural cures in Lachen, North Sikkim. Local medicines were mostly oriented on Buddhist religion in Sikkim at that time, and Lepchas had a reputation as adept botanists. As a result, missionaries in Sikkim considered nursing to be a more suitable task for serving the local communities. Edla and Hanna also worked in the Buxa region, selling herbal remedies and providing nursing care to the sick. Kaarlo and Hanna Waismaa worked in Ringim, Sikkim, teaching local women about basic cleanliness and health awareness (particularly communicable diseases), as well as spreading child care awareness among young mothers. They've also worked with Lapers who had been shunned by society because they were unclean. Kaarlo and Hanna visited lapers' homes and did various awareness campaigns.

\section{Translation and Documentation Works}

A Tibetan ABC Book and a songbook were jointly published by Fredrik Franson and David Macdonald (an interpreter of SAM leader Franson) among the few Christian publications and leaflets by Finnish missionaries. With the help of the Calcutta Department of the British and Foreign Bible Society, the New Testament Bible was also translated into two Tibetan dialects. It took ten years for the revised version of the New Testament Bible to be published, and the translation work is recognized as "the Ghoom Bible." Kaarlo Waismaa was a wellknown Finnish devotional song composer. She has translated a number of Finnish songs into Tibetan, as well as written and arranged music and released song books.

\section{Agriculture and Farming}

Klara Hertz, Edla Traskback, and Elin Kronqvist, three missionaries who stayed in Sikkim, taught the natives how to grow apple, potato, cabbage, and other crops. Sikkim's royal government has designated Lachen-Lachung Apple as "Mission Apple." In Lachen and Lachung, using climate-friendly agricultural products aids in the economic development of the local population. They were also allowed to market agricultural products to the rest of Sikkim, including Darjeeling and other districts, with the government's approval. Finnish missionaries taught locals how to make apple juice, which they sold to the Sikkim royal government from Mission House in Lachen.

\section{G. CONCLUSION}

"Socio-economic impact" refers to any direct or indirect significant consequences of a transaction on a local community's social or cultural conditions, livelihood, indigenous knowledge systems, or technology, as well as the country's economy.

The Finnish Free Mission, founded in 1889, and the SAM Mission, a minor player in the Himalaya, had a considerably longer impact on the lives of Himalayan and sub-Himalayan natives from the early nineteenth century to the mid-nineteenth century. For decades, Finnish missionaries have helped Himalayan and sub-Himalayan peoples strengthen their social and economic livelihoods through a number of actions. Women empowerment and girls' education along with basic health facilities are the major tools exercised by the Finnish missionaries made long term impact on Himalayan women population of Sikkim and Darjeeling towards self-sustainability. Besides, women missionaries from Finland done tremendous job towards the upliftment of economic stability, trade, commerce of Himalayan natives to a great extent.

\section{Acknowledgement}

I would like to express my sincere thank to Sir L.B. Rai, Gangtok, Sikkim for an assistance and sharing important documents (unpublished) related to Finnish mission work in Sikkim (Lachen, Lachung and Ringim), and Mr. Chewang Pintso Bhutia, North Sikkim for comments and valuable insights on Finnish mission work that greatly improved the manuscript. I would also like to show sincere gratitude to Mr. Sanjay Samuel Rai, Asst. Teacher, Scottish Mission Universities Institution, Kalimpong and Sir Juhani Kivela, Finland for sharing their pearls of wisdom with me during the course of this research, and also thank to "anonymous" reviewers for their so-called insights.

\section{REFERENCES}

1. Mukherjee B.K. \& A.V.A. Mercer (1962): A short History of Darjeeling District and its Hill people, Kurseong St. Alphonsus Press. 
2. Perry, Cindy L. (1997): Nepali around the World: Emphasizing Nepali Christians of the Himalayas, Ekta Books \{Appendix F (unpublished account by Miss Vappu Rautamaki, retired missionary of the Free Church of Finland, Himalayan Mission. Translated into English by Rebecca Scotson, TS dated 1994) Pgs. $420-$ 442\}.

3. Rai, Manidash (2009): Himalayan Free Church of Finland - sanchipta itihaas 1864 iswi dekhi 1950 iwsi-samma (NEPALI). Mukhdhara, Deorali, Gangtok, Sikkim.

4. Sandman E \& Virtanen, R.J. (2011): Himalayan Nature Representations and Reality, Studia Orientalia, vol. 109, 2011 (ISSN 0039-3282; ISBN 978-951-9380-75-9), University of Helsinki, Finland.

5. Vainonen, P.; Features of the Daily life in the Scandinavian Alliance Mission Stations in Sikkim, 1895-/1910. (https://shsfinland.files.wordpress.com/2018/11/v ainonen1.pdf). 10/02/2021.

\section{WORK CITED FROM INTERNET}

1. https://darjeeling.gov.in/about-district/ (12/05/2021)

2. https://www.hfci.info/history $(14 / 05 / 2021)$

3. http://jalpaiguri.gov.in/\# (11/05/2021)

4. https://www.sikkimtourism.gov.in/Public/index (21/05/2021)

5. https://kalimpong.gov.in/about-district/ (22/05/2021)

6. https://en.wikipedia.org/wiki/DHR (20/05/2021)

7. https://en.wikipedia.org/wiki/Lepcha_people (25/05/2021)

\section{PERSONAL}

\section{COMMUNICATIONS/UNPUBLISHED}

\section{DOCUMENTATION}

1. L.B. Rai, communication by author, 22nd April 2020.

2. Juhani Kivela, communication by author, $11^{\text {th }} \&$ $15^{\text {th }}$ July 2019.

3. Chewang Pintso Bhutia, communication by author, $27^{\text {th }}$ February 2019. 